\title{
NEW TECHNIQUE OF COMPRESSION ANASTOMOSIS IN COLORECTAL SURGERY - FIRST RESULTS IN 25 PATIENTS IN MACEDONIA
}

\author{
Svetozar Antovic ${ }^{1}$, Aleksandar Mitevski², Aleksandar Karagozov', \\ Biljana Kuzmanovska ${ }^{1}$, Nikola Jankulovski ${ }^{1}$ \\ ${ }^{1}$ University Clinic of Digestive Surgery, Medical Faculty, Skopje, R. Macedonia \\ ${ }^{2}$ Clinical Hospital, Stip, R. Macedonia \\ Corresponding Author: Nikola Jankulovski, University Clinic of Digestive Surgery, Medical Faculty, Skopje, \\ R. Macedonia; E-mail: prof.jankulovski@gmail.com
}

\begin{abstract}
Aim: Clinical evaluation of the safety and effectiveness of compression anastomosis with ColonRing ${ }^{\mathrm{TM}}$ for large-bowel end-to-end anastomosis for rectal cancer and explanation of the procedure and the device itself since this device is used for the first time in our clinic.

Material and methods: In November, 2012, a team of surgeons from our clinic attended the Clinical practice workshop in Belgrade, Serbia which was organized by the World Congress of Compression Anastomosis (WCCA) and held by its President Prof. Dr. Steven Wexner from Cleveland Clinic in USA. On this workshop, all aspects of technical point of view were obtained and surgeons were certified for the technique. A total of 25 patients have been scheduled for elective colorectal surgery with subsequent compression anastomosis using ColonRing. All patients were operated for high and mid rectal cancers excluding the low rectal cancers, since those patients are usually diverted with decompressive ileostomy. Patients, who are diverted, are at higher risk of retaining the ring, after its dislodgement, in the ampulla of the rectum since they do not have natural excretion of stool via the anus. All patients were followed for anastomotic leak, anastomotic bleeding, stricture formation, device (ColonRing) handling in general and time of expulsion of the ring via anus.

Results: We used this technique for the first time in 2013 and since then a total of 25 patients underwent anterior resection of the rectum with subsequent colorectal compression anastomosis using ColonRing. Of all patients, 9 were female while 16 were male with median age of 64 years. All patients were operated for rectal cancers. The mean length of hospital stay was 7.4 days (range 5 to 9 days). None of the patients developed anastomotic bleeding or dehiscence. To date none of the patients developed anastomotic stricture, although some patients were followed for almost two years. The average day of expulsion from the body could not be calculated since despite, and although all patients were given instruction on how to check for ring expulsion, 21 of them did not report this event. Only 2 patients brought the ring to us. In two cases after 2 week of the initial operation, the ring was find and palpated on digital rectal examination, free in the ampulla of the rectum and was easily removed via the anus during the examination. Misfiring was reported in 1 patient (first patient) and reanastomosis was employed using another ColonRing, No perioperative mortality was observed in this patient population.

Conclusion: End-to end colorectal anastomosis with the ColonRing is feasible and safe procedure with fast learning curve. To date, this type of anastomosis is possible in left sided colon lesions where anastomosis is contemplated below the promontory. We find the device easy to use with high level of confidence. Further prospective studies including comparison between the ColonRing device and the conventional staplers evaluating long-term anastomotic complications (i.e., leak or stricture) are needed to evaluate the benefits and limitations of this device.
\end{abstract}




\section{Introduction}

The resection of part of the bowel with subsequent anastomosis (reattachment) is widely used as surgical procedure of choice for various pathologies of the colon and rectum and all colorectal surgeons are closely familiar with this procedure, striving to make it better. Anastomotic leakage is one of the most serious early complications of any intestinal anastomosis, with a reported incidence rate of $1.3 \%$ to $21 \%$ [1]. Complete understanding of the mechanism of how anastomosis heals (connecting two luminal structures) is of crucial importance for the gastrointestinal anastomosis and is imperative to reduce the incidence of complications and dehiscence. Moreover, long-term functionnal outcome in patients might be adversely affected by anastomotic leakage [2].

The process of intestinal anastomotic healing can be divided into acute inflammatory (lag) phase, proliferative phase, and, finally, remodeling or maturation phase. The most important molecule for determining the intestinal wall strength is collagen, which makes its metabolism of particular interest for understanding the anastomotic healing. The factors that influence the fate of the anastomosis are both technical and patient-dependent. Currently, there are 3 available techniques for anastomosis: hand sewn, stapling, and compression. The techniques involving sutures and staples are the most widely used techniques for making bowel anastomosis with no significant advantage proven for any of them, although staplers, where possible, seem to be the surgeon preference since their usage shortens the operation time [3]. These two techniques use the penetration of foreign material into the tissue (sutures or staples), leading to breaking of the mucosal barriers and localized inflammatory response that may facilitate bacterial growth within the anastomotic line (anastomositis), thus increasing the propensity to anastomotic-related morbidity. This is the reason why we are still far from the ideal technique of anastomosis. In this regard investigators are still working on finding the most efficient way of bowel anastomosis that will reduce to the minimum the bowel wall injury and leaving no foreign material in the body of the patient. And this is where the concept of compression anastomosis comes. This is con- cept that was proposed for a very long time but till now, no device made it popular or convinced the surgeons in its own safety and usability.

The guiding principle of compression anastomosis is joining together and holding together in inversion manner both bowel ends that are compressed to each other until the natural healing process creates bowel continuity, and therefore, no foreign material is left in the body of the patient [4]. Compression devices have been long ago proposed and used clinically with varying degrees of success [5]. The idea of compression anastomosis has been proposed by Felix-Nicholas Denans, in 1928 [6]. Compression anastomosis was based on two opposing rings that trap the ends of transect bowel. Denans has suggested the compression anastomosis concept by applying silver or zinc rings in canine models for constructing end to end anastomosis. Bonnier, in 1885, and Murphy, in 1892, designed the first devices for performing anastomosis, which consisted of 2 metallic rings [7]. AKA-2 is a not-absorbable device, which was designed for colorectal anastomosis by Kanschin in 1984 [8]. Valtrac biofragmentable anastomotic ring (BAR) is another device developed in 1985 by Hardy [9] and probably the best studied so far. Based on various investigations, BAR could be applied in surgeries on different parts of gastrointestinal tracts, and not only on the large bowel, but it did not gain sufficient popularity [10].

The ColonRing device (NiTi Surgical Solutions): Recently this device has attracted much attention since it is a contemporary product made of high quality materials that insure confidence. The device uses Nitinol [11] (Nickel Titanium Naval Ordinance Laboratory), an alloy of nickel and titanium, which is a temperaturedependent, shape-memory alloy (SMA) that has been used in the formation of compression anastomoses [12]. The metal is shaped under high temperatures, and when it is ice cooled (to less than $0^{\circ} \mathrm{C}$ ), it loses its rigidity and becomes flexible. These features are absent in all the previously described compression anastomosis devices.

The ColonRing device is remarkably similar to the regular circular stapler (Fig. 1). It is comprised of 2 main parts: an applier and an implanted compression element. The compression element is composed of a plastic anvil ring 
and a metal ring that bares shape memory NiTi alloy (nitinol) leaf springs (Fig. 2). The pursestring technique or any closed lumen technique (stapling technique) may be used to place anvil into the organs to be anastomosed based on the surgeon's experience or judgment. When "fired" the rings are locked together by circumferentially placed barbed points, which penetrate through the tissue (Fig. 3) and the Nitinol springs that exert the desired constant controlled pressure force (7.7 Newtons or 1.65 Pounds). The device has a circular blade that cuts the tissue within the ring, creating patent anastomosis. The tissue heals around the circular edges that are held within the ring, through simultaneous necrosis-healing process, and the device along with the compressed tissue is intended to slough off over the following 8 to 10 days, at which point the ring is expelled from the body with a later bowel movement. The result is a full circumferential, hemostatic-sealed anastomosis without any retained foreign material.

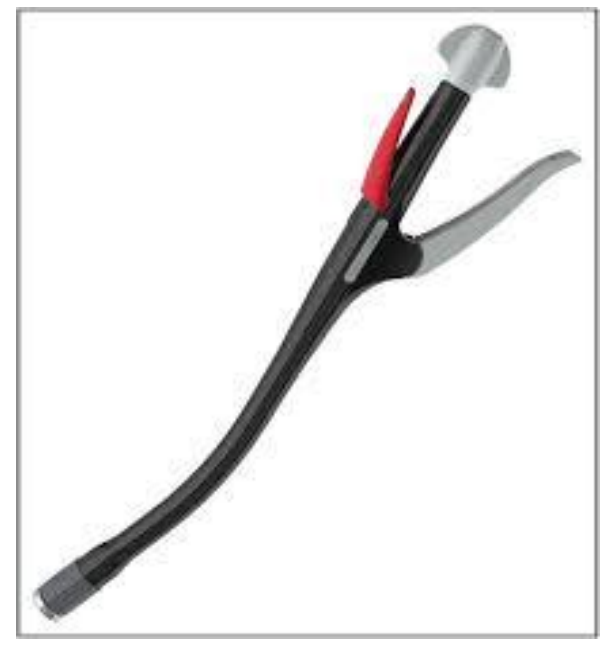

Fig. 1 - NiTi Coloring compression anastomosis device

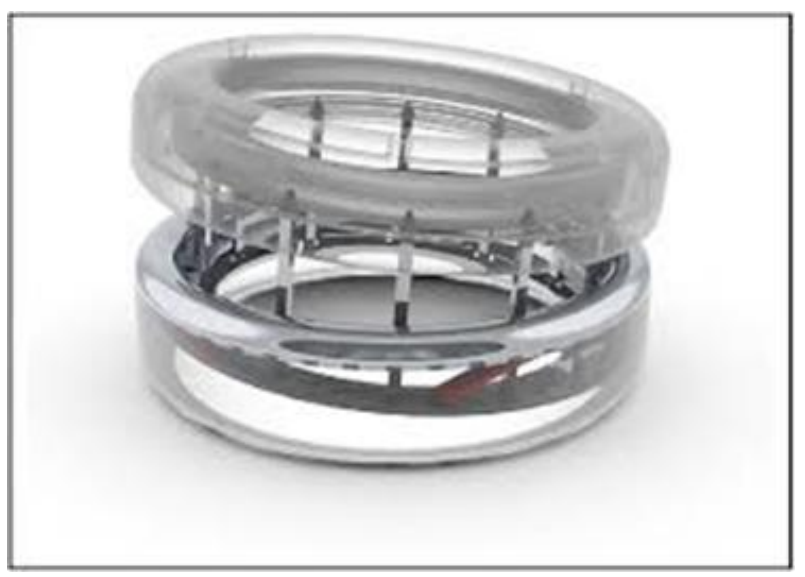

Fig. 2 - The compression anastomosis ring

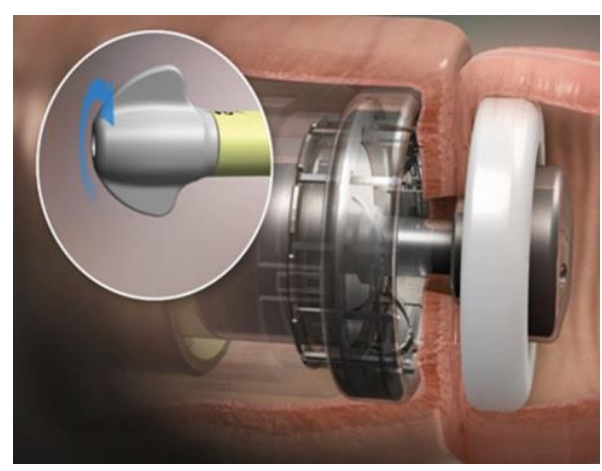

Fig. 3 - Endoluminal appearance of the two rings

The ColonRing device has been approved by the Food and Drug Administration (FDA) in 2006 for use in the colon and rectum for the creation of end-to-end and end-to side anastomoses in both open and laparoscopic colorectal surgeries. Studies have shown that the NiTi ColonRing device may overcome many limitations of the previous compression devices [13, 14] especially regarding the retained foreign material within the tissue (clips) that leads to constant inflammatory reaction that produces scar tissue and anastomotic stenosis. This is possible because of the basic nature of the compression anastomosis. The device provides for sufficient pressure for the proximal and distal tissue over a timeframe that allows for successful tissue healing, by the necrosis-healing process, by creating a zone of tissue necrosis internal to the apposed and healed tissue to allow expulsion of the ring into the lumen of the bowel followed by natural passage of the device from the body. After expulsion, no foreign material is left in the body of the patient to sustain further inflammation and there is no internal "lip" as in the stapler anastomosis, thus creating the largest possible anastomotic diameter than ever before of $27 \mathrm{~mm}$. (Fig. 4).

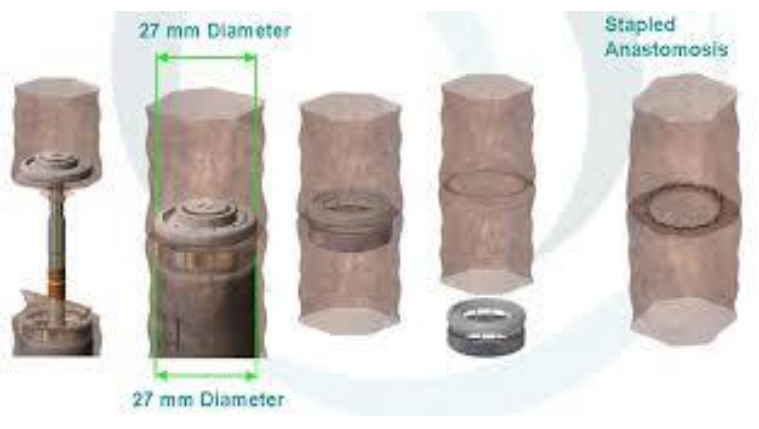

Fig. 4 - Difference between compression and stapled anastomosis 


\section{Aim}

Clinical evaluation of the safety and effecttiveness of compression anastomosis with ColonRing ${ }^{\mathrm{TM}}$ for large-bowel end-to-end anastomosis for rectal cancer and explanation of the procedure and the device itself since this device is used for the first time in our clinic.

\section{Material and methods}

In November, 2012, a team of surgeons from our clinic attended the Clinical practice workshop in Belgrade, Serbia which was organized by the World Congress of Compression Anastomosis (WCCA) and held by its President Prof. Dr. Steven Wexner from Cleveland Clinic in USA. On this workshop all aspects of technical point of view were obtained and surgeons were certified for the technique. Since 2013, a total of 25 patients have been scheduled for colorectal surgery with subsequent compression anastomosis using ColonRing. All patients were planned for elective operation of high and mid rectal cancers excluding the low rectal cancers, since those patients are usually diverted with decompressive ileostomy. Patients, who are diverted, are at higher risk of retaining the ring, after its dislodgement, in the ampulla of the rectum since they do not have natural excretion of stool via the anus. All patients were followed for anastomotic leak, anastomotic bleeding, stricture formation, device (ColonRing) handling in general and time of expulsion of the ring via anus.

\section{Results}

A total of 25 patients underwent anterior resection of the rectum with subsequent colorectal compression anastomosis using ColonRing. Of all patients, 9 were female while 16 were male with median age of 64 years. All patients were operated for rectal cancers. The mean length of hospital stay was 7.4 days (range 5 to 9 days). None of the patients developed anastomotic bleeding or dehiscence. To date none of the patients developed anastomotic stricture, although some patients were followed for almost two years. The average day of expulsion from the body could not be calculated, and although all patients were given instruction on how to check for ring expulsion, 21 of them did not report this event. Only 2 patients brought the ring to us. In two cases after 2 week of the initial operation, the ring was found and palpated on digital rectal examination, free in the ampulla of the rectum and was easily removed via the anus during the examination. Misfiring was reported in 1 patient (first patient) and reanastomosis was employed using another ColonRing, No perioperative mortality was observed in this patient population.

We find that using ColonRing is surprisingly similar to the conventional stapler device. Handling and firing is practically the same. The only difference is that when you open the package, one of the rings is not attached to the device (Fig. 5) since this is the part that holds the nitinol springs.

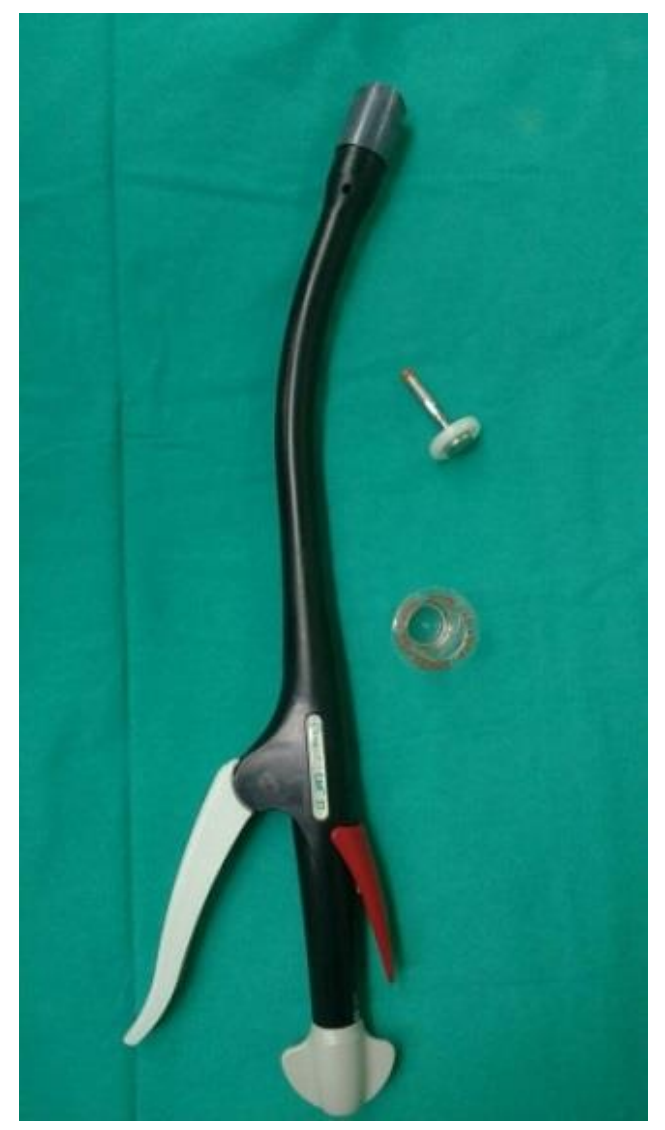

Fig. 5 - ColonRing device

Before the attachment to the device, this part is submerged in cold water below $5^{\circ}$ (Celsius) for 5 min (Fig. 6) and then is easily attached to the device by simply pushing and rotating the plastic holder (Fig. 7 and 8) 


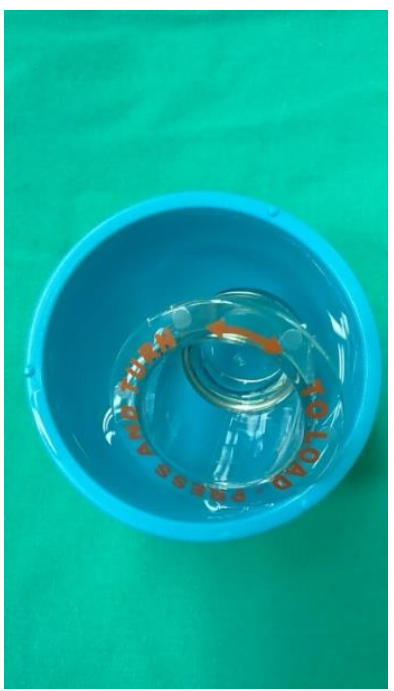

Fig. 6-Submerging in cold water
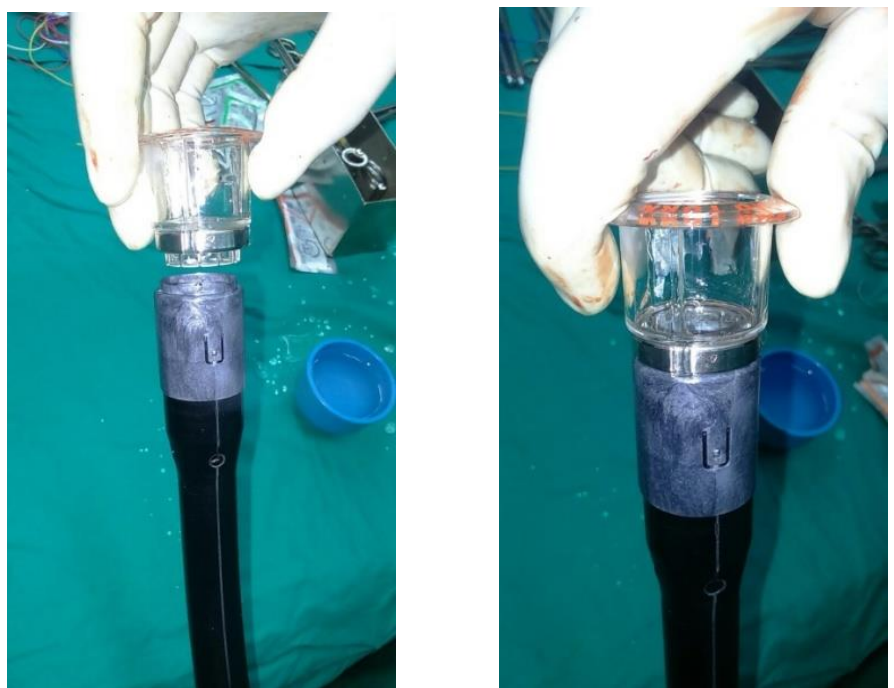

Fig. 7 and 8 - Placing the ring by rotation
From that point on, practically there is no difference with conventional stapler when it comes to handling. The anvil is placed in the

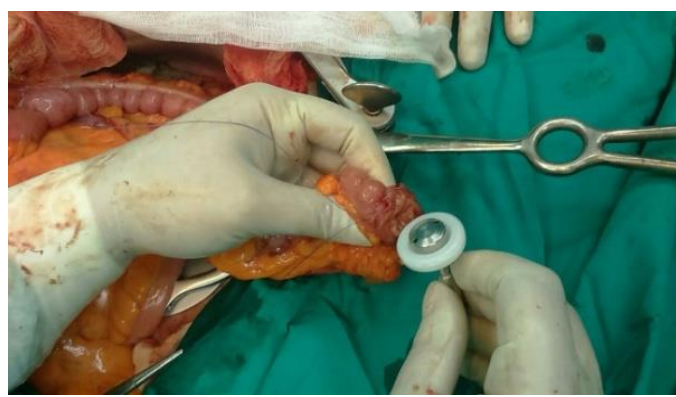

proximal colon (Fig. 9 and 10) and the device itself is placed via the anus in the distal rectum (Fig. 11).

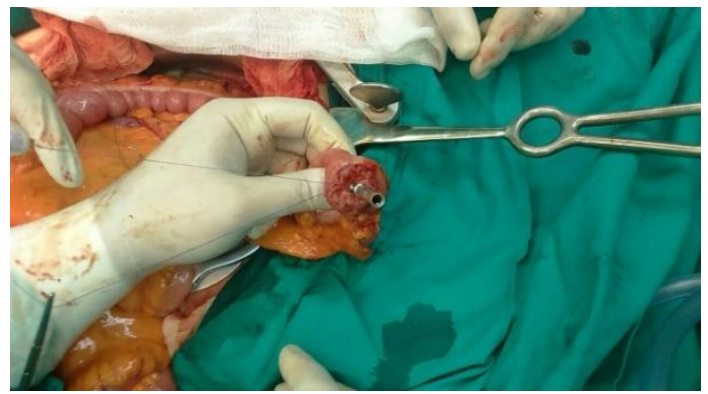

Fig. 9 and 10 -Placing the anvil in the proximal bowel lumen

Then the anvil and the device are connected and with simultaneous pressure on the handle (Fig. 12) the ring is fired. The device is retracted from the anus and the two donuts are examined for continuity (Fig. 13). Since the whole ring stays in the lumen of the rectum (Figure 14), there is no need to swing away the handle since the anvil does not pass through the anastomosis itself and it is simply retracted from the rectum much easier than the conventional stapler.

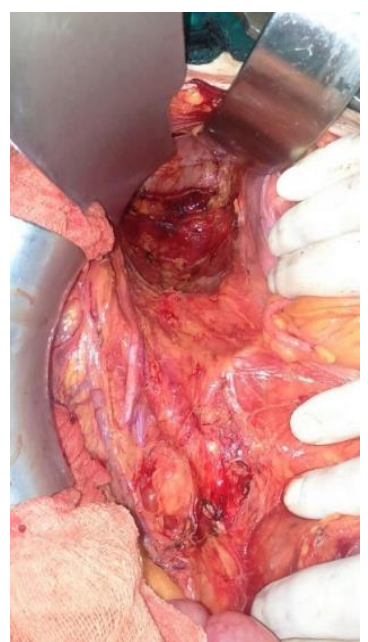

Fig. 11 - Distal transected rectum

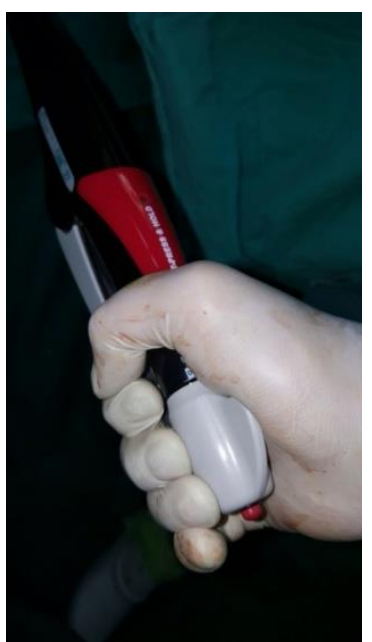

Fig. 12 - Firing the device

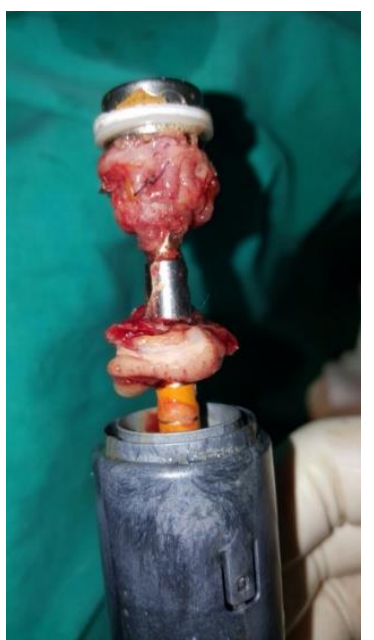

Fig. 13 - The two donuts 


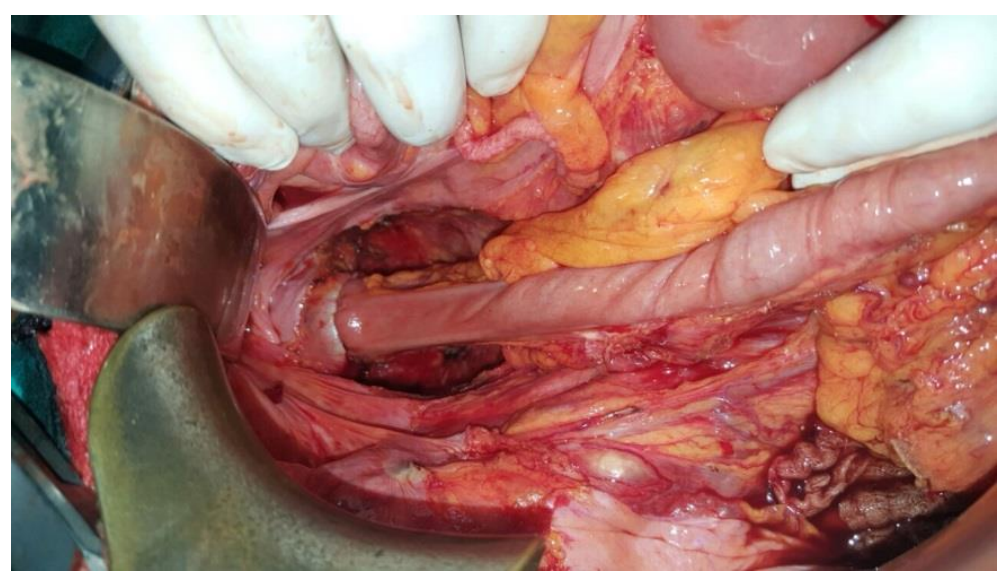

Fig. 14 -Anastomosis with compressive ring in the lumen of the bowel

In all 25 patients we did not encounter any problems with the use of the device. The scrub nurses quickly adapted to the technical aspect of the device and the attachment of the ring to the device itself.

\section{Discussion}

The incidence rate of anastomotic leakage is variable depending on the type of procedure, technique, level of anastomosis, and patient characteristics. Low anastomosis, male patients, and preoperative concomitant chemoradiotherapy have been shown to be independent risk factors for anastomotic leakage in rectal surgery [15]. By evaluating stapled versus hand-sewn methods for colorectal anastomosis, Neutzling et al. [16] in a recent systemic review study showed that the evidence was insufficient to show any superiority of stapled over hand-sewn techniques in colorectal surgery requiring anastomosis regardless of the level of anastomosis. Our study showed that the overall anastomotic leak rate using the NiTi ColonRing device was $0 \%$, which is within the expected range for this level of anastomosis (i.e., 3\% to 5\%) [17]. Hence, the NiTi ColonRing device can be considered safe in both laparoscopy and open surgery.

Two separate studies looked at bursting strength of the anastomotic site using compression or double stapling technique in a porcine model. Kopelman et al. [18] measured a mean bursting strength of $247.7 \mathrm{mmHg}$ (range 100$300 \mathrm{mmHg}$ ) in nine animals at time zero (immediately after the excision of the fashioned anastomosis). Furthermore Stewart et al. [19] revealed significantly higher bursting pressure after compression anastomosis in comparison with the conventional double stapling techni- que $(103,75.3 \mathrm{mmHg}$ vs $3,23 \mathrm{mmHg}$, respectively). Four of the nine compression anastomoses failed at the anastomotic line whereas nine of nine stapled anastomoses failed at the staple line (Fishers' exact test, $P<0.01$ ). Bursting pressures measured at two weeks after the anastomosis revealed equal pressures (266, $32.2 \mathrm{mmHg}$ and $230,87.5 \mathrm{mmHg}$, respectively). Compression therefore seems to be capable of overcoming anastomotic weakness during the 'classical' lag-phase and results in equal strength after detachment of the ring [20]. Based on that experience, a study was started in May 2007 in Uppsala (Sweden) and in Leuven (Belgium) to obtain clinical data in a consecutive group of 40 patients [21]. The recruited patients had either malignant or benign (diverticular) disease requiring resection with a high colorectal anastomosis (between 10 and $15 \mathrm{~cm}$ from the anal verge). The preliminary results of the study showed that of the first ten patients, nine underwent high anterior resection, and left colectomy was performed in one patient. No leak occurred in this first group of patients.

In 2013, using a multinational (16 countries), multicenter (178 centers) data registry, Masoomi et al. [22] published the largest, by number of patients, review study that showed that the overall anastomotic leak rate was $3.22 \%$ (38 patients). The median length of the hospital stay was 6 days (range 2 to 21 days). The median ring expulsion time was 8 days. The earliest ring expulsion time was 6 days; however, in 1 patient, the ring did not expel. In 4 patients, the anastomosis had to be immediately recreated because of 1 misfiring and 3 incomplete anastomoses. The authors concluded that the use of the ColonRing device is feasible 
and safe and could be considered an alternative technology for end-to-end colorectal anastomosis.

Although we do not have data supporting the nominal learning curve, this device functions almost identically to the current circular staplers in widespread use, facilitating the minimal learning curve. Overall, we felt that the device was easy to use and scrub nurses adopted to the technique very fast. Based on the current animal and clinical studies assessing compression anastomosis with the ColonRing device, there appears to be several potential benefits associated with its use. First, this technology delivers a constant stress plateau, which makes the ring detach from the anastomotic site at an appropriate and predictable time allowing for apposition of the bowel ends [23]. Second, the absence of foreign bodies at the anastomotic site may decrease inflammatory stimuli and formation of fibrous tissue as shown in animal studies, which may lower the risk for developing anastomotic stenosis [24]. Third, the absence of raw surface at the interface of the proximal and distal ends of the anastomosis with the ColonRing device may decrease the possibility of stricture and create a smooth and intact healing line [18].

However, our study lacked a long-term follow-up of patients, which makes it difficult to draw a conclusion on some important colorectal anastomosis-related complications, such as bowel stricture and obstruction. We did not have the ring expulsion time for all the patients; therefore, the reported ring expulsion time may not be accurate. Finally, our results report only on elective end-to-end colorectal anastomosis, and it could be different from the results of urgent surgery and/or other type of anastomoses (i.e., end-to-side and side-to-side anastomosis).

\section{Conclusion}

End-to-end colorectal anastomosis with the ColonRing is feasible and safe procedure with fast learning curve. To date, this type of anastomosis is possible in left sided colon lesions where anastomosis is contemplated below the promontory. We find the device easy to use with high level of confidence. The rate of anastomotic leak is relatively low with the use of the ColonRing for both open and laparoscopic colorectal anastomoses. Further prospective studies including comparison between the Colon-
Ring device and conventional staplers evaluating long-term anastomotic complications (i.e., leak or stricture) are needed to evaluate the benefits and limitations of this device.

\section{REFERENCES}

1. Choi DH, Hwang JK, Ko YT, et al. Risk factors for anastomotic leakage after laparoscopic rectal resection. J Korean Soc Coloproctol. 2010; 26: 265-73.

2. Fleshman JW, Nelson H, Peters WR, Kim HC, Larach S, Boorse RR, et al. Early results of laparoscopic surgery for colorectal cancer. Retrospective analysis of 372 patients treated by Clinical Outcomes of Surgical Therapy (COST) Study Group. Dis Colon Rectum. 1996; 39: S53-S58.

3. Lustosa SA, Matos D, Atallah AN, et al. Stapled versus hand sewn methods for colorectal anastomosis surgery (review). Cochrane Database Syst Rev. 2001; 3: CD 003144.

4. McCue JL, Phillips RK. Sutureless intestinal anastomoses. Br J Surg. 1991; 78: 1291-1296.

5. Hardy KJ. Non-suture anastomosis: the historical development. Aust N Z J Surg. 1990; 60: 625-633.

6. Kaidar-Person O, Rosenthal RJ, Wexner SD, et al. Compression anastomosis: history and clinical considerations. Am J Sur. 2008; 195: 818-826.

7. Murphy JB. Classical articles in colonic and rectal surgery. Cholecysto-intestinal, entero-intestinal anastomosis, and approximation without sutures. Dis Colon Rectum. 1981; 24: 51-59.

8. Kanshin NN, Lytkin MI, Knysh VI, et al. [First experience with application of compression anastomoses with the apparatus AKA-2 in operations on the large intestine]. Vestn Khir Im I I Grek. 1984; 132: 52-57.

9. Hardy TG, Jr., Pace WG, Maney JW, et al. A biofragmentable ring for sutureless bowel anastomosis. An experimental study. Dis Colon Rectum. 1985; 28 : 484-490.

10. Bubrick MP, Corman ML, Cahill CJ, et al. Prospective, randomized trial of the biofragmentable anastomosis ring. The BAR Investigational Group. Am J Surg. 1991; 161: 136-142.

11. Szold A. New concepts for a compression anastomosis: superelastic clips and rings. Minim Invasive Ther Allied Technol 2008; 17: 168-171.

12. Barras CD, Myers KA. Nitinol - its use in vascular surgery and other applications. Eur J Vasc Endovasc Surg 2000; 19: 564-569.

13. Stewart D, Hunt S, Pierce R, et al. Validation of the NITI Endoluminal Compression Anastomosis Ring (Endo CAR) device and comparison to the traditional circular stapled colorectal anastomosis in a porcine model. Surg Innov. 2007; 14: 252.

14. D'Hoore A, Hompes D, Folkesson J, et al. Circular 'superelastic' compression anastomosis: from the animal lab to clinical practice. Minim Invasive Ther Allied Technol. 2008; 17: 172-5.

15. Makela JT, Kiviniemi H, Laitinen S. Risk factors for anastomotic leakage after left-sided colorectal resec- 
tion with rectal anastomosis. Dis Colon Rectum. 2003; 46: 653-60.

16. Neutzling CB, Lustosa SA, Proenca IM, et al. Stapled versus handsewn methods for colorectal anastomosis surgery. Cochrane Database Syst Rev. 2012; 15: CD003144.

17. Hyman N, Manchester TL, Osler T, et al. Anastomotic leaks after intestinal anastomosis. It's later than you think. Ann Surg. 2007; 245: 254-8.

18. Kopelman D, Lelcuk S, Sayfan J, Matter I, Willenz EP, Zaidenstein L, et al. End-to-end compression anastomosis of the rectum: a pig model. World $\mathbf{J}$ Surg. 2007; 31: 532-537.

19. Starcher B, Fleshman J. Validation of the NITI Endoluminal Compression Anastomosis Ring (EndoCAR) device and comparison to the traditional circular stapled colorectal anastomosis in a porcine model. Surg Innov. 2007; 14: 252-260.

20. D'Hoore A, Hompes D, Folkesson J, Penninckx F, Pahlman L. Circular 'superelastic' compression anastomosis: from the animal lab to clinical practice. Minim Invasive Ther Allied Technol. 2008; 17: 172-175.

21. D'Hoore A, Hompes D, Folkesson J, Penninckx F, Pahlman L. Circular 'superelastic' compression anastomosis: from the animal lab to clinical practice. Minim Invasive Ther Allied Technol. 2008; 17: 172-175.

22. Masoomi H, Luo R, Mills S, Carmichael J, Senagore A, Stamos M. Compression anastomosis ring device in colorectal anastomosis: a review of 1,180 patients. The American Journal of Surgery. 2013; 205: 447-451

23. Song C, Frank T, Cuschieri A. Shape memory alloy clip for compression colonic anastomosis. J Biomech Eng. 2005; 127: 351-4.

24. Thiede A, Geiger D, Dietz UA, et al. Overview on compression anastomoses: biofragmentable anastomosis ring multicenter prospective trial of 1666 anastomoses. World J Surg. 1998; 22: 78-86; discussion 87.

Резиме

\section{НОВА ТЕХНИКА НА КОМПРЕСИВНА АНАСТОМОЗА ВО КОЛОРЕКТАЛНАТА ХИРУРГИЈА - ПРВИ РЕЗУЛТАТИ КАЈ 25 ПАЦИЕНТИ ВО МАКЕДОНИЈА}

Светозар Антовиќ ${ }^{1}$, Александар Митевски ${ }^{2}$, Александар Караѓозов ${ }^{1}$, Билјана Кузмановска ${ }^{1}$, Никола Јанкуловски ${ }^{1}$

${ }^{1}$ Универзитетска клиника за дигестивна хирургија, Медицински факултет, Скопје, Р. Македонија

${ }^{2}$ Клиничка болница, Штип, Р. Македонија

Цел: Клиничка евалуација на сигурноста и ефективноста на компресивната анастомоза со употреба на ColonRing ${ }^{\mathrm{TM}}$, како алтернативна ме- тода за креирање на анастомоза по ресекција на дебелото црево кај карцином на ректум, како и објаснување на самата процедура и инструментот со оглед дека се употребуваат првпат во нашата клиника и земја.

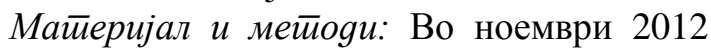
година, тим хирурзи од нашата клиника присуствуваа на работилница организирана од страна на Светското здружение за компресивни анастомози (WCCA) со кое раководеше претседателот на Здружението, проф. д-р Стивен Векснер, од клиниката Кливленд во Охајо, САД. На оваа работилница беа разгледани сите релевантни аспекти за креирање на компресивни анастомози со употреба на ColonRing и хирурзите беа сертифицирани за негова употреба. Вкупно 25 пациенти со висок или средно лоциран карцином на ректумот беа планирани за ресекциона хирургија и креирање на компресивна анастомоза. Сите пациенти беа планирани за елективен третман, додека исклучени од студијата беа итни пациенти и оние со низок карцином на ректумот кај кои вообичаено се прави ултраниска анастомоза со протективна илеостома. Сите пациенти беа следени за појава на дехисценција или крвавење на анстомозата, формирање на стриктура на местото на анастомозата, времето на експулзија на анастомозирачкиот прстен од телото на пациентите и осврт кон самата метода и инструмент.

Резулйайи: Првпат оваа техника беше употребена кај нас во 2013 година и оттогаш кај вкупно 25 пациенти беше направена предна ресекција на ректумот и компресивна анастомоза со употреба на ColonRing. Од пациентите, 9 беа жени, додека 16 мажи со средна возраст од 64 години. Просечното време на хоспитализација на пациентите беше 7,4 дена (5-9 дена). Кај ниеден пациент не се јави дехисценција или крвавење од анастомозата. Досега кај ниеден пациент нема стриктура на местото на анастомозата иако некои од пациентите беа следени повеќе од две години. Средното време на исфрлање на анастомозирачкиот компресивен прстен преку анусот не можеше да се пресмета бидејќи иако сите пациенти беа инструирани како да го пронајдат прстенот во столицата, сепак, само двајца пациенти успеале да го направат тоа. Кај двајца пациенти прстенот не беше спонтано исфрлен и тој, мануелно лесно, беше отстранет од страна на хирургот при контролен дигитален ректален преглед. Кај првиот пациент беше забележано неиспукување на прстенот при оперативниот зафат поради што се употреби втор ColonRing за креирање на анастомозата. Кај сите останати пациенти употребата на инструментот беше лесна. 
Во оваа група пациенти немаше периоперативен морталитет.

Заклучок: Крај со крај колоректалната анастомоза, креирана со употреба на ColonRing, е лесна и едноставна процедура со брза крива на учење. Засега, оваа техника на анастомоза се препорачува за заболувања на дебелото црево каде што се планира анастомоза под промонториумот. Сметаме дека употребата на инстру- ментот е едноставна и со големо ниво на сигурност. Понатамошни проспективни студии помеѓу ColonRing и конвенционалните степлери се неопходни за евалуација на долгорочните бенефити и лимитации на овој инструмент и на овој тип анастомоза.

Клучни зборови: анастомоза, колон, ректум, дехисценција, стеноза 